\title{
SUPPRESSION OF NONCONFESSIONAL EVIDENCE UNDER RULE 5(a) OF FEDERAL RULES OF CRIMINAL PROCEDURE*
}

EVIDENCE obtained as a result of illegal methods of federal law entorcement is excluded from federal criminal trials. ${ }^{1}$ Federal courts first employed exclusion of evidence to enforce the Fourth Amendment protection against unreasonable searches and seizures. ${ }^{2} M c N a b b v$. United States ${ }^{3}$ extended exclusion to confessions obtained during detention of arrested suspects contrary to the prompt arraignment requirements of rule 5(a) of the Federal Rules of Criminal Procedure. ${ }^{*}$ In both instances, the exclusionary rule sought to protect the substantive rights of individuals by deterring illegal methods of law

*United States v. Klapholz, 230 F.2d 494 (2d Cir. 1956).

1. The Supreme Court formulates general rules for admissibility of evidence under its authority to establish rules of evidence and procedure for federal courts. Wolfe v. United States, 291 U.S. 7 (1934) ; Funk v. United States, 290 U.S. 391 (1933). The Federal Rules of Criminal Procedure codify the principles announced in these decisions. FEd. R. CrIMr. P. 26. See Dession, The New Federal Rules of Criminal Procedure I, 55 YALE L.J. 694, 702-03 (1946). Drafted by an advisory committee and approved by the Supreme Court, the rules were submitted to Congress, see 18 U.S.C. $\$ 3771$ (1952), and have the effect of law, see Ochoa v. United States, 167 F.2d 341, 345 (9th Cir. 1948).

In addition to evidence secured by unreasonable search and seizure and illegal detention, see notes 2 and 3 infra, the Supreme Court has excluded evidence obtained by wiretapping in violation of $\S 605$ of the Federal Communications Act, 48 STAT. 1064, 1103 (1934), 47 U.S.C. $\S 605$ (1952). See Nardone v. United States, 308 U.S. 338 (1939). And confessions obtained by police fraud, intimidation or duress have long been subject to exclusion. See, c.g., Wilson v. United States, 162 U.S. 613 (1896); note 32 infra.

2. Boyd v. United States, 116 U.S. 616,635 (1882) first applied exclusion against unreasonable search and seizure. Although the Court relied on both the Fourth and Fifth Amendments, Boyd could apparently have been decided solely on the basis of the self-incrimination clause of the Fifth Amendment. Id. at 638 (concurring opinion); Comment, 58 Yale L.J. 144, 150 n.25 (1948). Weeks v. United States, 232 U.S. 383 (1914), first clearly enunciated the rule excluding evidence secured in violation of the Fourth Amendment alone.

3. 318 U.S. 332 (1943).

4. Rule 5(a) provides:

"An officer making an arrest under a search warrant issued upon a complaint or any person making an arrest without a warrant shall take the arrested person without unnecessary delay before the nearest available commissioner or before any other nearby officer empowered to commit persons charged with offences against the laws of the United States. When a person arrested without a warrant is brought before a commissioner or other officer, a complaint shall be filed forthwith."

The requirement of commitment "without unnecessary delay" establishes a single standard for all federal officers. It supersedes varied standards for different government agencies contained in statutes in effect when $M c N a b b$ was decided. See Act of March 1, 187\%, c. $125, \S 9,20$ STAT. 341, 18 U.S.C. $\$ 593$ (1940) (persons arrested for operating illicit distillery to be arraigned "forthwith"); Act of Aug. 18, 1894, c. 301, 28 St.sr. 416, as 
enforcement. $\sqrt{ }$ Reluctant to hamper unduly the enforcement activities of police agencies, federal courts have utilized the exclusionary rule with great restraint. ${ }^{6}$ The rule has thus been employed only where its value as a direct safeguard of individual rights clearly outweighs the resulting interference with federal law enforcement. ${ }^{7}$

Recently, the Supreme Court broadened the jurisdiction of federal courts to apply the rule in a decision which may also expand the types of evidence subject to exclusion. Rea $v$. United States ${ }^{8}$ held that a federal court may suppress evidence obtained by federal agents in violation of the Federal Rules of Criminal Procedure even if the evidence was to be used in a state prosecution. In Rea a federal agent who had acquired evidence of narcotics violations by an unlawful search and seizure was enjoined from testifying against the subject of the search in a state narcotics prosecution. ${ }^{9}$ The Court considered the

amended, 18 U.S.C. $\$ 595$ (1940) (arrests by United States Marshals); Act of June 18, 1934, c. 595, 48 Stat. 1008, 5 U.S.C. $\$ 300$ (a) (1940) (persons arrested by agents of the FBI to be arraigned "immediately"). See also McNabb v. United States, 318 U.S. 332, 342 (1943) ; Notes of Advisory Committee on Rules, rule 5(a), 18 U.S.C. $\$ 3771$ (1952).

5. See McNabb v. United States, 318 U.S. 332, 340, 343, 345 (1943) ; Weeks v. United States, 232 U.S. 383, 391-92, 393-94 (1914). See also Comment, 58 YALE L.J. 144, 150-52 (1948); Atkinson, Admissibility of Evidence Obtained Throngh Untreasonable Searches and Seizutres, 25 Colum. L. Rev. 11, 24-25 (1925) ; McCormick, Some Problems and Dcvilopments in the Admissibility of Confessions, 24 TexAs L. Rev. 239, 270 (1946).

6. In McGuire v. United States, 273 U.S. 95 (1927), holding a search warrant valid under the Fourth Amendment although officers had illegally destroyed the property seized, the Court declared: "A criminal prosecution is more than a game in which the Government may be checkmated and the game lost merely because its officers have not played according to rule." Id. at 99 . While this may overstate the attitude of federal courts toward exclusion, it is indicative of their efforts to adapt the exclusionary rule to the needs of law enforcement. Thus the rule may be invoked only by persons "aggrieved" by illegal acts, not others against whom evidence may be used. See FEv. R. CRrMr. P. 41 (e); Kelley v. United States, 61 F.2d 843, 845 (Sth Cir. 1932) ; Comment, 58 YaLE L.J. 144, 153-55 (1948) ; if. Goldstein v. United States, 316 U.S. 114, 116 (1942). But cf. United States v. Klapholz, 230 F.2d 494, 498 n.4. (2d Cir. 1956) (excerpted at note 22 infra). And to avoid a mechanical and inflexible operation of the rule the Supreme Court has often declared that no formula exists for determining the reasonableness of a search and seizure, each case requiring decision on its own facts. See United States v. Rabinowitz, 339 U.S. 56, 63 (1950) ; Go-Bart Importing Co. v. United States, 282 U.S. 344, 357 (1931). See, generally, Comment, 45 J. CRrM. L., C. \& P.S. 51 (1954). For similar attempts to reconcile the.$M c N a b b$ rule to police needs, see cases cited in notes 34-38 infra and accompanying text.

7. See, c.g., On Lee v. United States, 343 U.S. 747, 754-57 (1952); United States v. Mitchell, 322 U.S. 65, $70-71$ (1944); Carroll v. United States, 267 U.S. 132, 149 (1925).

8. 350 U.S. 214 (1956).

9. Rea was indicted on evidence obtained through a search warrant issued under rule 4l (a) of the Federal Rules of Criminal Procedure. Prior to trial he moved to suppress under rule $41(\mathrm{e})$ because the warrant lacked probable cause and was thus improperly issued under rule 41 (c). The district court granted the motion and the federal indictment was subsequently dismissed. However, the federal agent who had conducted the search then caused a state arrest warrant to issue for Rea's violation of New Mexico's narcotics law. The state prosecution rested entirely on the testimony of the federal agent. Prior to 
illegal act to violate federal rule 41 rather than the Fourth Amendment, ${ }^{\text {1n }}$ and interpreted the rules to give the judiciary "supervisory powers over federal law enforcement agencies." 11 These powers, it held, enabled federal courts to compel observance of the rules by suppressing evidence obtained in violation of the law enforcement standards they prescribe. ${ }^{12}$ Narrowly interpreted, the decision only extends the jurisdiction of federal courts to apply the exclusionary rule, without affecting the forms of evidence which may be excluded. The Court's language, however, discloses a possible new basis for suppression of evidence under the federal rules which ignores the exclusionary rule's original function of protecting individual rights. Rea's stress on the

the state trial Rea moved in the federal district court to enjoin the agent from testifying. This motion was denied and the Tenth Circuit affirmed. Rea v. United States, 218 F.2d 237 (10th Cir. 1953).

10. See text of rule 41 (e), note 20 infra.

Reliance on the Fourth Amendment might have forced the Court to reconsider difficult problems of federal and state criminal jurisdiction. In Wolf v. Colorado, 338 U.S. 25 (1949), the Court declared the exclusionary rule merely a federal rule of evidence for enforcement of the Fourth Amendment and not embodied within it substantively. Thus, while the substance of the Fourth Amendment is "implicit in the concept of ordered liberty" and enforceable against the states through the Fourteenth Amendment, id. at 27-33, fideral courts have no power to exclude unlawfully seized evidence from state prosecutiuns. Furthermore, prior to Rea the Court had refused to enjoin state officers from testifying in state prosecutions concerning illegally procured evidence. Stefanelli $v$ Minard, 342 U.S. 117 (1951). Though the Court indicated that exercise of such general equity pover: might be within its discretion, it refused to interfere with a state's administration of its own laws. The Rea dissent urged that the majority was indirectly doing this although unwilling to do so openly. 350 U.S. at 218. See Note, 56 Colum. L. REv. 940 (1956).

11. 350 U.S. at 217 . Previous cases applying the exclusionary rule provide no authority for such an assertion of power. The Court has always based the power to exclude illegally obtained evidence on its undoubted authority to supervise administration of federal justice by and in the federal courts. See note 1 supra. In excluding evidence tainted by federal police illegality, federal courts indicate their refusal to play any part in these illegal acts. See Weeks v. United States, 232 U.S. 383, 392 (1914). In McNabb v. United States, 318 U.S. 332, 347 (1943), the Court declared: "We are not concerned with law enforcument practices except in so far as courts themselves become instruments of law enforcement." See also United States v. Mitchell, 322 U.S. 65, 70-71 (1944); Note, 56 CoLvM. L. REv. 940,943 (1956).

12. As the Court itself indicated, 350 U.S. at 215 , the federal indictment charged at violation of an Internal Revenue Code provision, 50 STAT. 555 (1937), 26 U.S.C. $\$ 2593$ (a) (1952) (now INT. REv. CodE of 1954, $\$ 4744(a)$ ). Another law dealing with such violations, 28 U.S.C. $\$ 2463$ (1952), was thus applicable in Rea as a basis for suppression. This statute provides: "All property taken or detained under any revenue law of the United States shall not be repleviable, but shall be deemed to be in custody of the law and subject only to the orders and decrees of the courts of the United States having jurisdiction thereof." The district court's order might reasonably have been considered an "order and decree" preventing use of the evidence for any purpose, state or federal, and the injunction merely enforcement of this original order. By thus restricting Rea to its facts, the Court might reasonably have avoided a broad consideration of federal courts' "supervisory powers over federal law enforcement agencies." Furthermore, the language of rule 41 (e) itself could have upheld the injunction. See note $20 \mathrm{infra}$. 
duties of police agents suggests exclusion ${ }^{13}$ could be used to enforce observance of the federal rules regardless of the connection a violation may have to the evidence obtained.

Such an interpretation was adopted by a federal appellate court shortly after the Rea decision. In United States v. Klapholz ${ }^{14}$ the Second Circuit, apparently joining Rea's procedural holding with its substantive implications, extended the $M c N a b b$ rule of exclusion to nonconfessional evidence. Arrested for possessing contraband property, the defendants in Klapholz were arraigned after a period normally considered excessive under the $M c N a b b$ rule. ${ }^{15}$ Questioned after arrest, they had made incriminating admissions and agreed to cooperate in arresting consignees of the contraband by allowing government agents to remain with them in their apartment. During the more than thirtynine hours the agents were with defendants, they secured further incriminating admissions and such nonconfessional matter as testimonial evidence of phone calls overheard and arrests made of persons who came for the contraband. ${ }^{10}$ Invoking the Fourth Amendment and the $M c N a b b$ rule, defendants later moved in the district of detention, but prior to trial in the district of arrest, ${ }^{17}$ to suppress all evidence the agents had obtained while in the apartment. The district court held the defendants had waived their Fourth Amendment right by freely consenting to the presence of the agents in order to assist the arrest of the consignees. But viewing the detention in the apartment as an "unnecessary delay" of arraignment in violation of federal rule 5(a), it applied the $I I c N a b b$ rule to suppress all evidence obtained during the illegal detention. ${ }^{18}$

In affirming the order, the Second Circuit necessarily relied on Rea to uphold the district court's jurisdiction to suppress any evidence under $M c N a b b$. As the court itself recognized, federal rule 5(a) confers no authority at all for pre-trial suppression of evidence, and a district court other than the trial

13. For the purposes of this Note the terms "exclusion" and "suppression" are considered synonymous and will be used interchangeably except where discussion is specifically directed to procedures employed for enforcing the exclusionary rule.

14. 230 F.2d 494 (2d Cir. 1956), affirming 17 F.R.D. 18 (S.D.N.Y. 1955).

15. At 3:15 P.M. on August 2, 1954 defendants received a package at Idlewild Airport after signing a customs declaration that it contained only glassware. Customs agents who had observed defendants accosted them and searched the package, discovering a large cache of undeclared diamonds. Defendants were arrested at 4 P.M. on August 2 but not arraigmed until 1 P.M. on August 4. 17 F.R.D. at 20.

16. Phone calls were overheard at an extension attached to the telephone according to a pre-arranged agreement with defendants. Ibid.

17. Defendants were arrested in the Eastern District of New York but their apartment was in the Southern District. Ibid.

18. Actually, the district court found that failure to arraign from 8 P.M. on August 2, when defendants and agents first arrived at the apartment, until 10:30 A.M. on August 3, when a United States Commissioner would normally have been available, was not "unnecessary delay." However, further delay was unjustified and violated rule 5(a). The court accordingly applied $M C c N a b b$ to suppress only evidence acquired during this latter jeriod and denied the motion to suppress evidence previously obtained. Though tangible evidence was produced by search of the apartment just prior to arraignment, this evidence 
court clearly lacks this power. ${ }^{19}$ Rea, however, involved a violation of rule 41 (e), which permits pre-trial suppression by a district court of evidence obtained within its jurisdiction by unlawful searches and seizures. ${ }^{20}$ Nevertheless, the Second Circuit felt the Supreme Court's "language and rationale" allowed no distinction between rules 41 and $5(a)$ on this basis. Apparently, therefore, the court made two justifiable assumptions in interpreting Rea: the federal courts' "supervisory powers" over federal police agencies extend to enforcing the requirements of all the federal rules, and exercise of these powers by suppressing evidence to be used in another district is analogous to enjoining use of federally obtained evidence in a state court. ${ }^{21}$

The appellate court's seeming reliance on Rea to extend the McNabb rule to all types of evidence is more questionable than its use of the Supreme

was not suppressed since it was secured under a search warrant validly issued on August 2. Id. at $21-24$.

19. 230 F.2d at 496-97. But see In re Fried, 161 F.2d 453, 460 (2d Cir. 1947) (dissenting opinion).

20. Rule 41 (e) provides:

"A person aggrieved by an unlawful search and seizure may move the district court of the district in which the property was seized for the return of the property and to suppress for use as evidence anything so obtained .... If the motion is granted the property shall be restored unless otherwise subject to lawful detention and it shall not be admissible in evidence at any hearing or trial. The motion to suppres: evidence may also be made in the district where the trial is to be had. . . .

21. The Second Circuit felt that the "supervisory powers" concept authorized the Southern District to suppress evidence obtained in violation of rule 5(a) within the district. But, as the circuit court itself declared, the district court's action was discretionary since neither Rea nor any interpretation of rule 5 (a) compelled pre-trial suppression by a court other than the trial court for delay in arraignment. Indeed, there was a much greater need for pre-trial suppression in Rea. In that case, the injunction was necessary to provide defendant with any remedy at all, since the testimony of the federal agent would have: been admissible at the impending state trial. See Wolf v. Colorado, 338 U.S. 25 (1949); notes 10 and 12 supra. By contrast, defendants in Klapholz could probably have moved to suppress in advance of trial in the Eastern District. However, since the government had not objected to the motion on jurisdictional grounds, the Second Circuit found no abuse of discretion by the trial court. See 230 F.2d at $497-98$.

The Second Circuit's new procedure involves a substantial invasion of the jurisdiction of the trial court since the order of the Southern District is apparently res judicata at trial. See Steele v. United States No. 2, 267 U.S. 505 (1925) (previous decision validating search warrant held res judicata at trial) ; Dowling v. Collins, 10 F.2d 62 (6th Cir. 1926). Furthermore, since the Southern District order was made in an independent equitable proceeding, it could be appealed before trial. See 230 F.2d at 498 ; Dowling v. Collins, supra; cf. United States v. Rosenwasser, 145 F.2d 1015, 1017 (9th Cir. 1944). On the other hand, had the motion been made and ruled on before trial by the trial court, the order would not have been appealable, although improper admission of the evidence at trial could have been a basis for reversal on appeal following conviction. See Cogen $v$. United States, 278 U.S. 221, 223-25 (1929).

The court's theory for suppression under rule $5(a)$ is thus of substantial benefit to an accused. Since he now has the valuable option of moving to suppress in the district of detention as well as the district of trial, he may choose the court most likely to rule in his favor and may immediately appeal an adverse ruling in the district of detention. 
Court decision on the jurisdictional issue. Though the court did not expressly invoke Rea in suppressing nonconfessional evidence, it persistently cited language clearly suggesting a substantive extension of the exclusionary rule.22 Furthermore, without the support of Rea the Second Circuit would have entirely lacked other authority to extend $M c N a b b$, and in fact cited none. Consequently, Rea itself and its exact relation to $M c N a b b$ and Klapholz should be reviewed to determine whether the Second Circuit properly employed the Supreme Court decision to enlarge the scope of evidence excludable under federal rule 5(a). A second possibility, that the court may have extended the $M c N a b b$ rule independently of $R e a$, also requires critical evaluation.

Initially, it is doubtful the $M c N a b b$ rule should have been applied to suppress any evidence in Klaphols. Since the district court found that defendants waived their Fourth Amendment rights during detention by consenting to the presence of agents in the apartment, ${ }^{23}$ its decision, affirmed by the Second Circuit, that they had not also waived their rule 5(a) right to prompt arraignment seems anomalous under the facts of Klaphols. The evidence does not indicate defendants were more fully advised of their Fourth Amendment rights than of their rule 5(a) safeguards. By consenting to cooperate in the apprehension of other criminals they agreed to remain in police custody and thus were actually responsible for the delay in arraignment. And the district court itself suggests defendants had full control over the length of delay and could have terminated the detention at any time by simply refusing further assistance to the police. In fact, the police promptly arraigned defendants as soon as they indicated they would no longer cooperate. ${ }^{24}$ Furthermore, none of the

22. Quoting from Rea, 350 U.S. at 217-18, the Second Circuit declared:

"[T]he federal Rules 'are designed as standards for fedeal agents' . . . When 'a federal agent has violated the federal Rules governing searches and seizures ... [t]he power of the federal courts extend to policing those requirements and making certain that they are observed' .... It is true that here we are concerned with a suppression based on violation of Rule 5(a) instead of one based on violation of the Fourth Amendment which is the subject matter of Rule 41. But the language and rationale of the majority opinion in the Rea case permits no distinction on that account."

230 F.2d at 497. And later the court said:

"We have no need, therefore, now to determine whether the Rea decision may be invoked only by those whom federal agents have detained in violation of Rule 5(a) or whether in the exercise of its asserted power to discipline federal agents the Supreme Court intends that evidence obtained in violation of the Federal kules shall be inadmissible even against those not otherwise injured by executive action."

Id. at 498 n.4.

23. The district court declared: "The record also warrants a finding that the defendants' consent was not the result of coercion, fraud or threat of any kind." 17 F.R.D. at 21 .

24. In United States v. Grote, 140 F.2d 413, 415 (2d Cir. 1944), the Second Circuit itself established authority for waiver of prompt arraignment, expressly rejecting dictum in United States v. Haupt, 136 F.2d 661 (7th Cir. 1943), on which the Klaphols district 
rights rule 5(a) aims to protect were violated. Before consenting to cooperate, defendants were advised of their rights against self-incrimination and to coun$\mathrm{sel}^{25}$ one of the main goals of prompt arraignment. And probable cause for their arrest clearly existed since the arrest, itself never challenged, was the basis of validly issued search warrants. Inquiry into probable cause, another purpose of arraignment, was thus not urgent and in any event would have been a formality. ${ }^{26}$ Admittedly, as the district court noted, defendants could have been arraigned in chambers, thus fulfilling the formal requirement of rule $5(\mathrm{a})$ and permitting continuation of the plan of cooperation. ${ }^{27}$ But cooperation after arraignment would undoubtedly have produced precisely the

court relied in refusing to allow waiver. In Haupt there was no proof that defendants had voluntarily waived right to prompt arraignment. However, the court also discussed whether defendants can ever waive requirements of arraignment statutes similar to rule 5(a). It found that cases of waiver of jury trial, counsel, speedy trial and confrontation of witnesses involved provisions defining "rights of the individual," while statutory requirements of prompt arraignment defined "duties of arresting officers." The court suggested that allowing persons to "waive" officers' legal duties would defeat the intent of the arraignment statutes by making these duties depend on the action of individuals rather than the legislative mandate. Id. at 671 .

It seems clear, however, that both rule $5(\mathrm{a})$ and the $M c N a b b$ rule prescribe duties for arresting officers in order to protect rights of arrested persons. See United States v. Leviton, 193 F.2d 848, 862 (2d Cir. 1951) (dissenting opinion). See notes 29-34 infra and accompanying text.

25. 17 F.R.D. at 21 . See note 30 infra.

26. A preliminary hearing establishes whether sufficient evidence exists to warrant holding an accused for grand jury action. Barber v. United States, 142 F.2d 805, 807 (4th Cir. 1944); Note, 60 Y ALE L.J. 1228, 1235 (1951). Such evidence constitutes probable cause for arrest. However, the evidence required to establish probable cause for either arrest or search need not conform to trial standards. Brinegar v. United States, 338 U.S. 160, 173, 175-76 (1949); Note, 65 Y ALE L.J. 390,391 (1956). Brinegar declared the "probable cause exists where 'the facts and circumstances within ... [the officers'] knowledge and of which they had reasonably trustworthy information [are] sufficient in themselves to warrant a man of reasonable caution in the belief that' an offence has been committed." 338 U.S. at 175-76. Citing to this definition of probable cause in discussing the validity of the search warrants, the Klapholz district court found that defendants' receipt of the case containing contraband diamonds confirmed information received from a foreign confidential source concerning its shipment. 17 F.R.D. at 23-24. The court thus gives considerable weight to the confidential information possessed by the police which was the basis for defendants' arrest following discovery of the diamonds. Furthermore, the circumstances of defendants' arrest are analogous to those in an earlier Second Circuit decision holding such an arrest valid. In United States v. Poller, 43 F.2d 911, 912-13 (1930), federal agents suspected defendant of illegally importing Swiss watch movements. Their suspicions were verified on finding the contraband goods in a package which, according to defendant's statements to customs officials, contained chocolates. Following discovery of the contraband, defendant was arrested and charged with violation of a smuggling statute, Act of Sept. 21, 1922, c. 356, § 591, 42 STAт. 981, substantially the same as that involved in Klapholz. See 18 U.S.C. $\$ 545$ (1952), which reads in part: "Proof of defendant's possession of such goods, unless explained to the satisfaction of the jury, shall be deemed sufficient to authorize conviction for violation of this section."

27. 17 F.R.D. at 23. 
same evidence against defendants as was suppressed, for they evidently desired to aid the police. Consequently, failure to arraign was at most a technical violation of rule $5(\mathrm{a})$, and it is probable Klapholz did not fall within the $M c N a b b$ rule at all.

Even assuming the $M c N a b b$ rule applicable in Klapholz, the nature and function of the rule does not justify its extension to nonconfessional evidence. The Second Circuit's statement that exclusion under $M c N a b b$ was intended "as a deterrent to detention in violation of rule $5(\mathrm{a})$ "28 is an oversimplification not justified by decisions applying the rule. Actually, the substantive evil $M c N a b b$ seeks to prevent is police use of physical and psychological pressures during illegal detention to secure apparently "voluntary" confessions from arrested suspects. ${ }^{29}$ Prompt arraignment under rule 5 (a) is designed to protect the accused against such "third degree" practices by immediately affording him the benefits of counsel, bail ${ }^{30}$ and a judicial hearing. ${ }^{31}$ Prior to $M c N a b b$, a detained suspect

28. 230 F.2d at 498.

29. $M I c N a b b$ thus referred to prompt arraignment statutes:

"[T]his procedural requirement checks resort to those reprehensible practices known as the 'third degree' which, though universally rejected as indefensible, still find their way into use. It aims to avoid all the evil implications of secret interrogation of persons accused of crime."

318 U.S. at 344. See also United States v. Mitchell, 322 U.S. 65, 66-68 (1944) ; 4 REPoRT, Natronal Commission on Law Observance and Enforcenent 3, 4, 31-37, $152-72$ (1931) (hereinafter cited as Wickersham REPORT). And see, generally, HopkINs, OUR LAWLess PoLICE (1931).

Early applications of the $M c N a b b$ rule recognize that police use of "third degree" methods to extort confessions during illegal detention is the primary rationale for exclusion. See, e.g., United States v. Haupt, 136 F.2d 661, 668 (7th Cir. 1943); Gros v. United States, 136 F.2d 878, 880 (9th Cir. 1943); Mitchell v. United States, 138 F.2d 426 (D.C. Cir. 1943) ; United States v. Klee, 50 F. Supp. 679, 683 (E.D. Wash. 1943). Recent cases employing the rule adhere to this view. Tillotson v. United States, 231 F.2d 736, 737 (D.C. Cir. 1956) ; United States v. Leviton, 193 F.2d 848, 860-62 (2d Cir. 1951) (dissenting opinion); Haines v. United States, 188 F.2d 546, 552-53 (9th Cir. 1951).

Even commentators opposed in varying degrees to the $M c N a b b$ rule have recognized its relation to "third degree" practices and coerced confessions. See Waite, Police Regulalion by Rules of Evidence, 42 Mich. L. Rev. 679 (1944); Inbau, The Confession Dilemma in the United States Supreme Court, 43 ILt. L. Rev. 442 (1948); McCormick, Some Problems and Developments in the Admissibility of Confessions, 24 TexAs L. REv. 239 (1946). See also Hearings Before Subcommittee No. 2 of the House Committee on the Judiciary on H.R. 3690, 78th Cong., 1st Sess., ser. 12, at 11-17, 27-43 (1943) (hereinafter cited as Hearings). But for a strong argument that illegal detention is itself an evil aside from the aggravating effects of the "third degree," see A Statement by the CoMmitre on tHe Bill of Rights of the American Bar Association on H.R. 3690, at 9-15 (1944) (hereinafter cited as ABA Statement).

30. On arraignment under rule $5(a)$ the accused is immediately entitled to protection of rule $5(\mathrm{~b})$ which provides:

"The commissioner shall inform the defendant of the complaint against him, of his right to retain counsel and of his right to have a preliminary examination. He shall also inform the defendant that he is not required to make a statement and that any statement made by him may be used against him. The commissioner shall allow the 
was protected against such police techniques only if he could show his confession was coerced. The court would then exclude the confession on the ground that it was untrustworthy or involuntary. ${ }^{32}$ This protection proved largely ineffectual; in practice a defendant who had confessed was often unable to present enough proof of coercion to warrant exclusion. ${ }^{33}$ The $\mathrm{Mc}$ -

defendant reasonable time and opportunity to consult counsel and shall admit the defendant to bail as provided in these rules."

31. Rule 5 (c) describes the procedure for the preliminary examination.

The protections accorded an accused under rules $5(\mathrm{~b})$ and $5(\mathrm{c})$ make police use of "third degree" methods to extort confessions virtually impossible. See ABA Statenient 15-17. Following committment, the accused is placed temporarily in the custody of the Bureau of Prisons, 18 U.S.C. $\S 4042$ (1952), or a United States Marshal, 18 U.S.C. § 4086 (1952). Though United States Marshals are supervised by the Attorney-General, 28 U.S.C. $\$ 547$ (c) (1952), they are officers of the district court and responsible to it. 28 U.S.C. $\$ 547$ (a), (b) (1952). And an accused may be visited by friends and counsel while in custody; if freed on bail he is entirely beyond the reach of the police until trial. See Note, 60 Y ALE L.J. 1228, 1235 n.35 (1951); Comment, 53 id. 758, 769 n.73 (1944).

32. No clear rule exists to which federal courts may refer in excluding coerced confessions. Such confessions have been held inadmissible because they are involuntary, Lyons v. Oklahoma, 322 U.S. 596, 602 (1944), and untrustworthy, Hopt v. Utah, 110 U.S. 574, 585 (1884). See Note, 60 Y AlE L.J. 1228 \& nn.3 \& 4 (1951). Distinctions between voluntariness and trustworthiness are, however, primarily historical rather than practical since the same evidence of coercion is generally sufficient to exclude on either grounds. Inbau, supra note 29, at 442 \& n.2, 443; McCormick, The Scope of Privilege in the Law of Evidence, 16 Texas L. Rev. 447, 452-57 (1938). For the view that only trustworthiness should control see WIGMTORE, EVIDENCE $\$ \S 822-26$ (3d ed. 1940).

In using the voluntary-trustworthy test federal courts have usually relied on long standing rules of evidence rather than constitutional provisions. See, e.g., Wilson v. United States, 162 U.S. 613, 621-23 (1896). Yet in Bram v. United States, 168 U.S. 532, 542 (1897), a forced confession was held violative of the Fifth Amendment privilege against self-incrimination. See McCormick, supra at 451-54. And in Brown v. Mississippi, 297 U.S. 278 (1936), the Court first invoked the due process clause of the Fourteenth Amendment to reverse a state conviction based on a forced confession. Lisbena v. California, 314 U.S. 219, 236 (1941), later deemed such evidence fundamentally unfair to an accused "whether true or false." Apparently, therefore, the proper ground for exclusion of federally obtained coerced confessions is the due process clause of the Fifth Amendment, though federal courts have never specifically excluded the confession on this basis. See, however, suggestions in Upshaw v. United States, 335 U.S. 410, 414 n.2 (1948) ; Waley v. Johnston, 316 U.S. 101, 104 (1942); United States v. Klee, 50 F. Supp. 679, 682 (E.D. Wash. 1943). See also Inbau, supra at 443; Comment, 53 YALE L.J. 758, 759 (1944); ABA STATEMEXT 50.

33. Federal trial courts have broad discretion to decide admissibility. See Wilson $v$. United States, 162 U.S. 613, 624 (1896) ; United States v. Echeles, 222 F.2d 1H, 155 (7th Cir. 1955). If evidence of coercion is conflicting the judge may admit the confession and allow the jury to decide credibility. See Anderson v. United States, 318 U.S. 350, $351 \mathrm{n.1}$ (1943); Wilson v. United States, supra at 624. However, once the defendant raises the coercion issue the burden of proving the confession was volurtary rests on the government. See United States v. Echeles, supra at 155; Patterson v. United States, 183 F.2d 687, 68990 (5th Cir. 1950).

The exclusionary rule as actually applied by federal courts affords the defendant a protection more nominal than real. Since questioning takes place incummunicado, it is: invariably difficult for the defendant to establish coercion. See United States v. Mitchell, 
$N a b b$ rule helped an accused overcome this difficult evidentiary obstacle by automatically excluding the confession on the basis of a presumption that a confession obtained during illegal detention was coerced. ${ }^{34}$ The most recent Supreme Court interpretation of the rule indicated the government could overcome this presumption only by showing the confession was obtained before the detention became illegal. ${ }^{35}$

322 U.S. 65, 68 (1944) ; United States v. Leviton, 193 F.2d 848, 862 (2d Cir. 1951) (dissenting opinion); ABA STATEMENT 17. The defendant must thus rely on his bare assertion of duress and on the circumstances surrounding his questioning. See Bram v. United States, 168 U.S. 532, 548-49 (1897) ; Hopt v. Utah, 110 U.S. 574, 583-84 (1884). And this may not be sufficient to overcome a presumption that an innocent man will not prejudice his interests by falsely confessing. See Davis v. United States, 32 F.2d 860, 862-63 (9th Cir. 1929). Furthermore, police officers are likely to deny their wrong. Thus, even where extrinsic circumstances hint strongly at coercion, see, e.g., Ruhl v. United States, 148 F.2d 173, 174 (10th Cir. 1945), faced with conflicting testimony, the judge or jury might be more influenced by an accused's probable guilt than by the possibility his constitutional rights were violated. See McCormick, supra note 29 , at 250 . And the judge may overrule the defendant's objections or admit the confession for the jury's consideration because of reluctance to brand officers who took it as liars. See McCormick, supra at 25051. See, generally, Hopkins, Our Lawless Police 288-313 (1931). But see Ashcraft v. Tennessee, 322 U.S. 143, 148-54 (1944), where, influenced by $M c N a b b$, the Court held a state confession inadmissible because the circumstances of its acquisition were "inherently coercive."

34. Neither rule 5(a) nor Supreme Court decisions interpreting it specify what constitutes "unnecessary delay" in arraignment. In $M c N a b b$ v. United States the Court declared: "the mere fact that a confession was made in custody of the police does not render it inadmissible." 318 U.S. at 348. Subsequent lower court decisions applied the $M c N a b b$ rule inflexibly and mechanically to exclude almost any confession made prior to arraignment, regardless of the length or circumstances of detention. See Mitchell v. United States, 138 F.2d 426 (D.C. Cir. 1943) ; United States v. Hoffman, 137 F.2d 416, 421 (2d Cir. 1943); United States v. Haupt, 136 F.2d 661, 668 (7th Cir. 1943). See also unreported cases cited in Comment, 53 YaLE L.J. 758, 763 n.37 (1944). More recently, however, most lower federal courts have departed from this rigid interpretation and have considered the legality of detention in terms of its reasonableness under the circumstances. These courts generally require defendant to prove the detention unreasonable. See, e.g., Tillotson v. United States, 231 F.2d 736, 738 (D.C. Cir. 1956) ; White v. United States, 200 F.2d 509, 512 (5th Cir. 1952); United v. Leviton, 193 F.2d 848, 854 (2d Cir. 1951). Nevertheless, it is much casier for the accused to establish the fact of illegal detention than that he was forced to cunfess during incommunicado interrogation. ABA STATEMENT 17.

35. The Court has never clearly indicated whether the presumption of coercion is conclusive on the issue of admissibility, or rebuttable. In United States v. Mitchell, 322 U.S. 65, 67, 69 (1944), the Court admitted a confession made shortly after arrest although the defendant was later detained for eight days without arraignment. Holding that subseunent illegality could not require exclusion of the prior voluntary confession, the Court found the confession was not "induced" by illegal detention. However, Upshaw v. United States, 335 U.S. 410, 413 (1948), later held that a confession made during illegal detention was inadmissible whether or not it resulted from physical or psychological duress. Distinguishing Mitchell on the ground the confession there was made before illegal detention, the Court seemingly indicated that a confession made during illegal detention was conclusively presumed to be coerced. And evidence of voluntariness could not rebut this presumption. But Upshaa's suggestion that the confession was actually the motive for 
Exclusion under $M c N a b b$ accordingly demands the existence of a causal relation-either actual or presumed-between the evidence excluded and the illegal means used to obtain it. Judicial notice of police activities enables this causal relation to be justifiably presumed with confessional evidence. ${ }^{30}$ Yet many lower federal courts exclude even such evidence only where circumstances clearly indicate the confession obtained was either the motive for failure to arraign promptly ${ }^{37}$ or at least its direct result. ${ }^{38}$ On the other hand, no reasonable basis exists for presuming a causal relation between violation of rule $5(\mathrm{a})$ and acquisition of nonconfessional evidence by generalizing from past experience and knowledge of police techniques. ${ }^{39}$ Nor is such detention as occurred in Klapholz necessarily motivated by a desire to acquire nonconfes-

police illegality leaves this issue in doubt for it is still arguable that the confession there was produced by illegal detention. Furthermore, the $L^{\prime} p$ shaze dissent interpreted $1 /$ it $h$ chll to support the proposition that even confessions made during illegal detention are admissible if not induced by the detention. Id. at 421-24, 429-34. The District of Columbia Circuit, moreover, has elaborated this doctrine in a series of more recent cases in which the Supreme Court has repeatedly denied certiorari. See, e.g., Allen v. United States, 202 F.2d 329, 334 (D.C. Cir.), cert. denied, 344 U.S. 869 (1952) ; Pierce v. United States, 197 F.2d 189, 193 (D.C. Cir.), cert. denied, 344 U.S. 846 (1952). See also Watson v. United States, 234 F.2d 42, 47 (D.C. Cir. 1956); Tillotson v. United States, 231 F.2d 736, 737-38 (D.C. Cir. 1956). Other circuit courts have construed Upshaw' as automatically excluding confessions during detentions proved unreasonable. See note 34 supra. But by considering the government's rebutting evidence on the factual issue of reasonableness of delay in arraignment, these courts have admitted confessions even where detentions were quite lengthy. See White v. United States, 200 F.2d 509 (5th Cir. 1952); Duncan v. United States, 197 F.2d 935, 937 (5th Cir. 1952); United States v. Leviton, 193 F.2d 848 (2d Cir. 1951) ; Haines v. United States, 188 F.2d 546, 550-51 (9th Cir. 1951); United States v. Walker, 176 F.2d 564 (2d Cir. 1949). See, generally, Note, 100 Li. PA. L. Rrv. 136 (1951).

36. See, generally, Hopkins, Our Lawless Police (1931); Wickersham Repurt. See United States v. Mitchell, 322 U.S. 65,68 (1944), for other studies of the relation between illegal detention and "third degree" practices used to secure confessions. Set also note 29 supra.

37. See, e.g., Tillotson v. United States, 231 F.2d 736, 737 (D.C. Cir. 1956). Ste also Note, 100 U. PA. L. Rev. 136 (1951).

38. Where the evidence clearly indicates the police failed to arraign promptly for the very purpose of inducing a confession, the confession so obtained is unquestionably inadmissible. Often, however, the court must infer this relation between detention and confession since no clear evidence of improper police motives may exist. See cases citcd in note 35 supra.

39. Neither the studies of police activities which greatly influenced the formulation of the $M c N a b b$ rule nor the cases interpreting it indicate the rule was intended to apply: to nonconfessional evidence. See, generally, Hopkins, Our Lawless Police (1931); WiCKERSHAM REPORT; Hearings. Even commentators violently opposed to the rule consider only its application to confessions and incriminating admissions. See Waite, supro note 29 ; Inbau, supra note 29 . Furthermore, the Preliminary Draft of the Federal Ruleof Criminal Procedure which embodied the $M c N a b b$ rule in rule 5 (b) clearly referred to statements made by a defendant in response to interrogation. Advisory CoMmitieE, Federal Rules of Criminal Procedure 11 (prelim. draft 1943). 
sional evidence against the arrested suspect; it may be used chiefly in order to secure evidence against others involved in the crime. ${ }^{40}$

Moreover, while incommunicado detention provides excellent opportunity to obtain confessions otherwise difficult to secure, the police will hardly use it to acquire nonconfessional evidence since far more effective legal means are available. Klapholz itself dramatically illustrates this as applied to testimony of police officers. Since the suspects would probably have cooperated in the same fashion had they been arraigned, the police would have legally acquired the same nonconfessional evidence against them as was suppressed. Furthermore, such police testimony is generally secured through surveillance of suspected criminals before arrest or arraignment. And tangible evidence, which though not involved in Klapholz, comes within the Second Circuit's broad decision, is usually acquired by searches and seizures. ${ }^{41}$ Delayed arraignment is thus clearly unnecessary for this purpose. Klaphols's extension of the $M c N a b b$ rule thus neglects the causal relation which should exist between illegal detention and evidence obtained if the rule is properly invoked. The availability of other routine and legal techniques for securing nonconfessional evidence suggests the extension will in any case be of minimal practical utility in preventing evils of police activity against which the rule was originally designed.

Since neither previous judicial construction of the $M c N a b b$ rule nor analysis of the rule itself provides authority for its extension to nonconfessional evidence, any decisional support for Klapholz must be sought in Rea. This support necessarily rests on the contention that Rea altered the rationale for exclusion under $M c N a b b$ from deterrence of "third degree" methods to direct discipline of federal agents for all infractions of the Federal Rules of Criminal Procedure. The Supreme Court's suppression of evidence for a violation of rule 41 is thus construed to make police observance of the federal rules an end in itself. Under this interpretation, delay in arraignment requires suppression of evidence whether confessional or nonconfessional and regardless of any curtailment of individual rights.

40. In some cases, however, the evidence obtained may be used against the arrested suspect. Under conspiracy doctrine, the acts and admissions of one conspirator may be used to incriminate his co-conspirators. Pinkerton v. United States, 328 U.S. 640 (1946). If such a causal relation between evidence and illegal detention is actually found to exist, even nonconfessional evidence should be excluded under the $M c N a b b$ rule. But where the detention is voluntary, as in Klapholz, the defendants may consider concessions likely to result from cooperation to outweigh the possibility of further incrimination. See text following note 15 supra and notes 23-27 supra and accompanying text.

41. All tangible evidence secured at the Klapholz apartment was acquired under a validly issued search warrant. See note 18 supra; Letter from Leonard P. Moore, United States Attorney, to the Yale Lazo Journal, June 29, 1956, on file in the Yale Law Library. Even had there been no search warrant, however, defendants' original waiver of Fourth Amendment rights might have precluded reliance on the amendment to suppress tangible evidence. The court might then have suppressed under $M c N^{\top} a b b$ despite the obvious lack of relation between the detention and the tangible evidence secured through search of the apartment. 
Significant differences between rule 41 and rule 5(a) indicate Rea does not provide authority for the Second Circuit's decision. Unreasonable searches and seizures-violations of the Fourth Amendment itself statutorily embodied in rule 41 -directly produce the evidence later suppressed; a causal relation between the violation and the evidence secured is thus always self-evident. Moreover, federal courts have refused to suppress evidence because of seemingly technical and inadvertent infringements of the Fourth Amendment or rule 41 , holding these so minor as not to be violations at all. ${ }^{42}$ Whenever such infringements have been the apparent basis for suppression, the violation had in fact reached the very substance of the protection afforded. ${ }^{43}$ On the other hand, violations of rule 5 (a) do not uniformly contain the causal factor.44 Only where it is presumed or found has evidence been suppressed in the past. And because courts have placed strong emphasis on the need for a causal relation between confession and illegal detention, Rea probably did not intend to reach violations of rule 5 (a) not involving this factor.

This causal relation, in fact, should be a necessary condition of any suppression of evidence if the rule is properly to accomplish its acknowledged objective of protecting individual rights while permitting the most efficient law enforcement. Mechanical applications of a rule like that of $M c N a b b$ without regard to the causal factor would often place irrelevant technicalities in the path of criminal administration..$^{45}$ Such results have been upheld on the ground that the exclusionary rule expresses community sentiment favoring strict observ-

42. See McGuire v. United States, 273 U.S. 95, 98 (1926) (illegal destruction of property seized in search); Hurley v. United States, 300 Fed. 75 (1st Cir. 1924) (same); Giacolone v. United States, 13 F.2d 108, 109 (9th Cir. 1926) (failure to leave copy of warrant and receipt for property taken); United States v. Clark, 298 Fed. 533 (S.D. Ala. 1924) (same). And failure to give a receipt for the items taken did not invalidate the search or constitute a violation of the Fourth Amendment in Klaphols itself. 17 F.R.D. at 24 .

43. Even slight deviations from the requirement of particularity of description of the premises to be searched have been held to violate the Fourth Amendment protection against general exploratory searches. See, e.g., United States v. Hinton, 219 F.2d 324, 326 (7th Cir. 1955) (affidavit established probable cause to search the residences of four persons referred to by aliases; warrant directing search of entire building consisting of four apartments insufficient for lack of particularity) ; Bucari v. Fili, 31 F. Supp. 433 (M.D. Pa. 1940) (search warrant describing premises as next door, south, of 512 Main Street in Old Forge insufficient description where there was a North and South Main Street in Old Forge).

In Sgro v. United States, 287 U.S. 206 (1932), the Court again invalidated a search warrant because it infringed another apparently technical requirement. Sgro held that violation of the statutory ten-day period for return of the warrant, see FEn. R. CRIM. P. 41 (d), made the warrant invalid. However, a substantive right was involved. Seasonable return of the warrant was held closely related to the necessity that probable cause exist when a warrant is issued. The Court found in effect that after ten days probable cause for the search no longer existed, and that it must be shown again to procure a new warrant. Sgro v. United States, supra at 210-11.

44. See notes 34-38 supra and accompanying text.

45. See Hearings 1-10, 32-34. 
ance of statutory procedures by federal agents. ${ }^{46}$ Adherents of a disciplinary approach further argue for applying exclusion to every police infraction on the theory that rights of every member of the community are jeopardized each time federal agents violate constitutional or statutory safeguards. ${ }^{47}$ These arguments, however, overlook the duty of federal courts to implement all aspects of law enforcement, not simply one over others equally important. The police must effectively protect the community from criminal activity. When the protection an exclusionary rule affords to individual rights is more theoretical than real, applying the rule places a needlessly heavy burden on law enforcement agencies. ${ }^{48}$ The exclusionary rule is therefore at best a practical compromise for reconciling conflicting values neither of which can be denied, and courts must have some standard by which to determine whether specific violations warrant its application. The most effective device presently available for satisfying these demands is the requirement of a causal relation between illegality and evidence secured.

46. For the classic statement of this view, see Olmstead v. United States, 277 U.S. $438,469-85$ (1928) (dissenting opinions).

47. Ibid.; ABA Statement 3-23.

48. Upshaw v. United States, 335 U.S. 410, 414 (1948) (dissenting opinion); Waite, Police Regulation by Rules of Evidence, 42 Mrcm. L. Rev. 679 (1944); Inbau, The Confession Dilcmma in the United States Supreme Court, 43 ILL. L. REv. 442 (1948); Hearings 46-60. 